
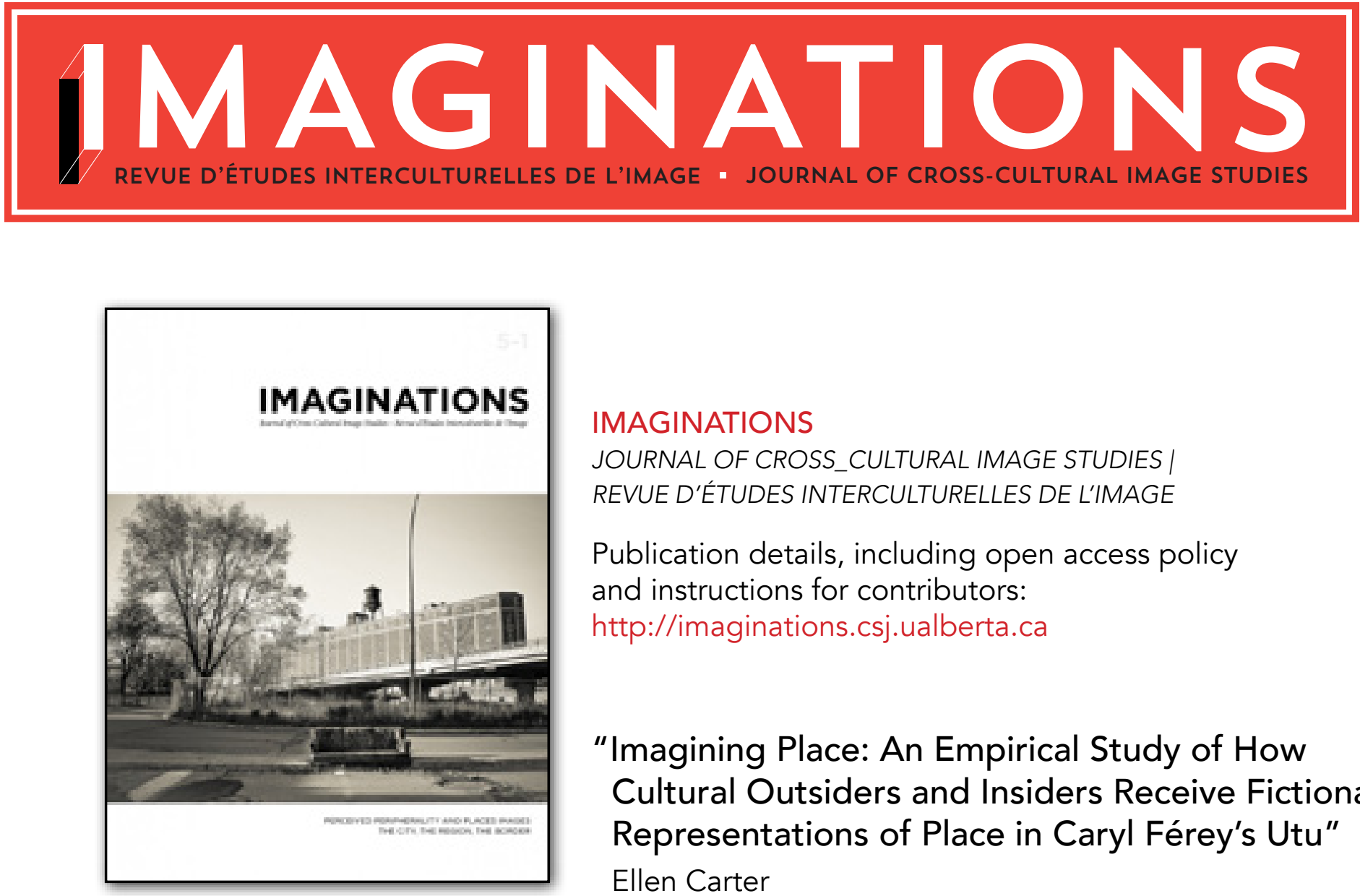

\title{
IMAGINATIONS
}

JOURNAL OF CROSS_CULTURAL IMAGE STUDIES |

REVUE D'ÉTUDES INTERCULTURELLES DE L'IMAGE

Publication details, including open access policy

and instructions for contributors:

http://imaginations.csj.ualberta.ca

"Imagining Place: An Empirical Study of How Cultural Outsiders and Insiders Receive Fictional Representations of Place in Caryl Férey's Utu" Ellen Carter

March 28, 2014

To Cite this Article:

Carter, Ellen. "Imagining Place: An Empirical Study of How Cultural Outsiders and Insiders Receive Fictional Representations of Place in Caryl Férey's Utu" Imaginations 5:1 (2014): Web (date accessed) 67-80. DOI: 10.17742/IMAGE.periph.5-1.5

To Link to this article:

http://dx.doi.org/10.17742/IMAGE. periph.5-1.5

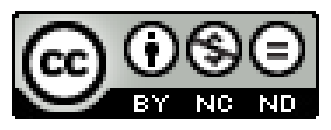

The copyright for each article belongs to the author and has been published in this journal under a Creative Commons Attribution NonCommercial NoDerivatives 3.0 license that allows others to share for non-commercial purposes the work with an acknowledgement of the work's authorship and initial publication in this journal. The content of this article represents the author's original work and any third-party content, either image or text, has been included under the Fair Dealing exception in the Canadian Copyright Act, or the author has provided the required publication permissions. 


\section{IMAGINING PLACE: AN EMPIRICAL STUDY OF HOW CULTURAL OUTSIDERS AND INSIDERS RECEIVE FICTIONAL REPRESENTATIONS OF PLACE IN CARYL FÉREY'S UTU \\ ELLEN CARTER, UNIVERSITY OF AUCKLAND}

I provide empirical evidence from a longitudinal cross-cultural reader reception survey showing that cultural outsider (French) and insider (New Zealand) readers are differently influenced by the geographically and culturally-situated elements in Utu (French 2004, English translation 2011), a crime novel set in contemporary New Zealand by French writer Caryl Férey. After reading the novel, both cultural outsider and insider readers changed their opinions towards the image portrayed by Férey, even when his cultural claims were incorrect. Furthermore, for French readers, this influence extended beyond Utu's final page to opinions about New Zealand and its inhabitants.
Cet article veut offrir la preuve empirique que les lecteurs provenant respectivement d'une culture extérieure (France), et intérieure (Nouvelle-Zélande), sont influencés différemment par les éléments géographiquement et culturellement situés dans Utu (France 2004; traduction anglaise 2011), un roman policier de l'auteur français Caryl Férey se déroulant dans la Nouvelle-Zélande d'aujourd'hui. Létude s'appuie sur une enquête longitudinale interculturelle de la réception au sein du lectorat. Après lecture du roman, les lecteurs culturellement externes et internes ont chacun changé leur opinion quant à l'image véhiculée par Férey, même lorsque ses représentations culturelles s'avèrent incorrectes. Qui plus est, aux yeux des lecteurs français, cette influence sétend au-delà du roman lui-même, et semble se porter sur la Nouvelle-Zélande elle-même, avec ses habitants. 
French crime writer Caryl Férey (b. 1967) spent only five months in New Zealand before publishing a novel set there: Utu (2004, English translation 2011), in which Pakeha(New Zealander of European origin) policeman Paul Osborne investigates a cannibalistic Māori separatist sect. He discovers that his half-Māori childhood sweetheart has joined the separatists but that the real criminals are corrupt Pakeha politicians and businessmen who are dynamiting an ancient Māori village site to make way for a multimillion dollar beach resort and who try to throw Osborne off their scent by framing him for the rape and murder of a high-profile, mixed-race model.

My study applies social science approaches to humanities data in order to identify differences between the reception of this culture-specific text by cultural insiders (New Zealanders) and cultural outsiders (French readers). I am not interested in whether readers give the 'correct' answer to cultural questions (if such a thing exists) but how and why the opinions they hold are, or are not, influenced by their reading of this novel. Utu is useful for cross-cultural reader reception because it embodies extremes: (1) Férey spent only months in New Zealand before publishing Utu; (2) France and New Zealand--united by rugby but separated by nuclear testing--have few contemporary or historical touch points in common thus their distance, psychological and geographical, makes difference easier to identify and then explain; (3) Māori have a distinct and distinctive culture with a globally recognised iconography; and
(4) Utu was translated by an Englishman for an American publishing house. While it can be dangerous to extrapolate from extremes--risking Manichean generalisations that deny an issue's fine structure--they do help to make difference visible.

Cross-cultural empirical reception studies loom largest in film and television studies (for example, Barker and Mathijs; Crofts). Equivalent textual studies are less common, perhaps due to "the antiempirical climate of the Anglo-American literary academy at large" (Richardson 11). However, there are exceptions, such as Carroll et al.s study of nineteenthcentury British novels, which surveyes "faculty in English departments worldwide" (3) but does not report results by respondent location. Childress and Friedkin's empirical sociological study (55), while not cross-cultural, examines longitudinal changes in readers' attitudes to a novel before and after a book-club meeting to test the influence of the discussion process on reception. Halász, Short and Varga compare responses from German, British and Hungarian school students to three short texts but do not explore their respondents' cultural insider/outsider positions relative to these texts. Thus my paper reports the first empirical, longitudinal, cross-cultural investigation of the influence of a novel on its readers' opinions. 


\section{Method}

I started with four hypotheses about the relationship between a reader's geographical and cultural background and their response to Utu, or how the place of reading influences the reading of place:

Hypothesis 1. That cultural-outsider (French) readers are more influenced than cultural-insider (New Zealander) readers by Utu's geographically- and culturallysituated elements, such as political, anthropological, historical, and social depictions;

Hypothesis 2. That cultural outsider (French) readers are more influenced by depictions of certain aspects of New Zealand and/or Māori culture than by other aspects;

Hypothesis 3. That the perceived source of the geographically- and culturallysituated information influences readers' reception; and

Hypothesis 4. That French readers change their attitudes to New Zealand and New Zealanders based on their reading of a novel set in that country.

To test these hypotheses, I developed two sets of dependent variables: (1) twenty-seven statements about New Zealand and Māori culture (see Table 1), which I used with both the French and New Zealand participants; and (2) eight attitude statements about New Zealand and New Zealanders (see Table 2), which I used only with French participants. I asked participants to indicate their level of agreement with each statement on a seven-point Likert-type rating scale from $1=$ 'completely disagree' to $7=$ 'completely agree.'

All twenty-seven statements in Table 1 appear in Utu, but this does not mean that this information is necessarily accurate (for a discussion of Utu's cultural errors, see Carter and WalkerMorrison). Nineteen statements are made by the narratorial voice, one by a protagonist, Osborne, and seven by an antagonist, Melrose. These last seven are inflammatory; I included them to test my third hypothesis about whether reader response is affected by the information's perceived source. 
Table 1: Twenty-seven statements about New Zealand and Māori culture used as dependent variables with both French and New Zealand participants

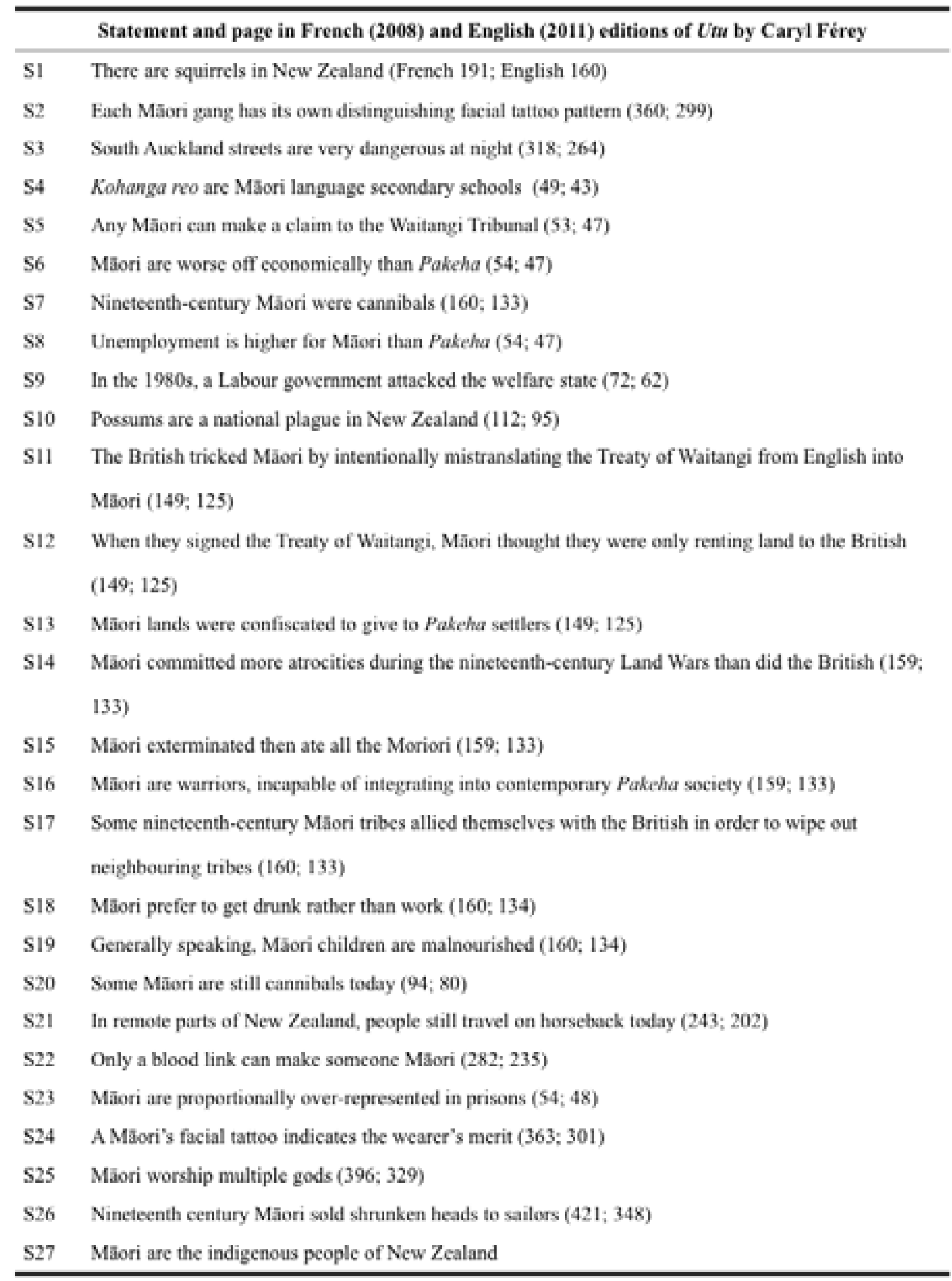


Table 2: Eight attitudinal statements about New Zealand and New Zealanders used as dependent variables only with French participants

Attitudinal statement
A1 Jai l'intention de visiter la NZ au cours des trois prochaines années.
A2 En NZ, les visiteurs se sentent en sécurité.
A3 Les néo-zélandais sont amicaux.
A4 En NZ, je pourrais être victime d'un crime.
A5 On m'a dit que la NZ est un pays dangereux.
A6 Les néo-zélandais sont dignes de confiance.
A7 Je conseillerais aux amis de faire attention à la criminalité en NZ.
A8 Les néo-zélandais sont sympathiques.

Of the eight attitudinal statements (see Table 2), I adapted five (A1, A2, A4, A5, A7) from George's (812) South African study of visitor perception of crime-safety and attitudes to risk, and two $(\mathrm{A} 6, \mathrm{~A} 8)$ from a study investigating changing attitudes and country image (Auruskeviciene et al. 55). I added A3 because 'friendliness' is an attribute often mentioned by overseas visitors to New Zealand but it barely features in Férey's novel.

Since I was interested in if and how participants' opinions were changed by reading $U t u$, I used a repeated measures design. I gave pre-reading questionnaires and numbered copies of Utu in French to 119 students enrolled in English courses at Université Paris-Sorbonne, as well as pre-reading questionnaires and numbered copies of Utu's English translation to 114 students enrolled in French or Māori Studies courses at the University of Auckland, New Zealand. As well as demographic information, these pre-reading surveys asked for participants' opinions about twenty-seven statements (see Table 1) on contemporary New Zealand and/or Māori culture and society. Participants were invited to read the novel then complete an on-line postreading questionnaire that asked for their opinions about the same twenty-seven statements, presented in a random order. They also had to report their novel's number so I could match pre- and postreading responses. I received twenty-six $(21.8 \%)$ post-reading responses from French and twenty-four (21.1\%) from New Zealand participants.[1]

My research design is quasi-experimental (Black 69-70), using pre- and post-test observations but with a non-equivalent control group, i.e. New Zealand participants. Given the key constraint to my study--that participants had to read a crime fiction novel in their own time before responding to an online post-reading questionnaire--I could not rely on experimental rigour controlling 
for some variables. Nonetheless, my repeated measures design helps control for between-readers differences in textual reception (Halász, Short and Varga 195). Using the survey research method allowed me to quantify how respondents felt about issues to do with New Zealand and Māori culture, and how this knowledge and opinions were (or were not) influenced by the participant's reading of $U t u$.

\section{Results and Discussion[2]}

\section{Hypothesis One: That cultural outsider} (French) readers are more influenced than cultural insider (New Zealander) readers by Utu's geographically- and culturally-situated elements

My null hypothesis - $\mathrm{H}_{0} 1$ - is that cultural outsider and insider readers were similarly influenced by Utu's geographically- and culturallysituated elements, such as political, anthropological, historical, and social depictions. I tested this in two ways: by looking at the degree of correlation between pre- and post-reading responses for each cohort, then by comparing pre- and post-reading responses at the individual reader level.

Degree of correlation between pre-and post-reading responses

My research design involved nonindependent observations since I measured participant responses to the same questions on two different occasions. However, the degree of correlation between these pre- and postreading responses differed between the two cohorts; while a paired sample t-test showed that the pre- and post-reading responses to only two (S3, S20) of the twenty-seven questions were statistically significantly positively correlated for French readers, this was true of sixteen questions asked of New Zealanders. This provides evidence to reject $\mathrm{H}_{0} 1$ since it shows that New Zealanders were more likely than French readers to give similar pre- and post-reading responses, indicating that reading $U t u$ had not changed their opinions.

\section{Change in pre- and post-reading responses}

I ran Wilcoxon signed ranks test for related samples to compare responses before and after reading $U t u$ for French and New Zealand respondents. Table 3 shows the number of statements for which the pre- and post-reading results showed a statistically significant difference for each cohort, as well as whether this difference was a change towards the opinion depicted by Férey in Utu. Given that the pre- and postreading opinions of French respondents was statistically significantly different for twenty statements - compared to only seven for New Zealand respondents - this provides further support to reject $\mathrm{H}_{0} 1$ and accept $\mathrm{H} 1$, that cultural outsider (French) readers were more influenced than cultural insider (New Zealand) readers by Utu's geographically- and culturallysituated content.

Yet even New Zealanders were not left entirely unmoved by reading $U t u$. Their opinions about three statements changed from 'disagree' to 'don't know', a change in the appropriate direction in two cases: S5 properly recognises that "any 
Table 3: Summary of results from Wilcoxon signed ranks tests on pre- and postreading responses to twenty-seven statements by French and New Zealand readers

\begin{tabular}{lcc}
\hline & French & New Zealand \\
\hline Statistically significant difference and & 7 & 3 \\
mean moved from 'disagree' to 'agree' & & $4(p<0.05)$ \\
Statistically significant difference but mean & 13 & $2 \quad(0.05<p<0.1)$ \\
did not cross scale's mid-point & & 18 \\
No statistically significant difference & 7 & \\
\hline
\end{tabular}

Māori person may submit a claim to the Waitangi tribunal" ("Making a Claim") and S7 reflects current thought about nineteenth-century Māori cannibalism (at least pre-1815, Barber 242), although scholars disagree over the reasons, from meeting spiritual (Barber 280) to physical needs (Salmond 142). However, New Zealanders were wrong to change from 'disagree' to 'don't know' for S4 since kohanga reo are Māori language preschools, not secondary schools. Férey has his half-Māori heroine, Hana Witkaire, attend one throughout high school as a way of showing her embracing her Māori heritage; his depiction was sufficiently forceful to overcome New Zealanders' prior knowledge.

Table 3 also shows that Férey's influence is not monolithic: French (and New Zealand) readers changed their opinions about some elements but not others, leading to my next hypothesis, examining which aspects are more persuasive.
Hypothesis Two: That cultural outsider (French) readers are differently influenced by certain aspects of New Zealand and/or Māori culture

From the results in Table 3, I can immediately reject my null hypothesis: $\mathrm{H}_{0} 2$ - that cultural outsider readers are similarly influenced by all the different aspects of New Zealand and/or Māori culture portrayed by Férey in $U t u$. The more interesting question is whether there are commonalities between the cultural aspects of $U t u$ that are (not) persuasive, because this might shed light on which cultural elements are (not) influential. To investigate this I looked at French responses and compared the seven statements grouped in Table 3's top row - statistically significant difference and a change from 'disagree' to 'agree': S3, S4, S7, S15, S17, S23, and S16 - with the seven in the table's bottom row - no statistically significant difference: S1, S14, S18, S19, S20, S21, and S27 - to try to identify factors that could account for these differences. 
I classified each statement by whether it deals with a contemporary or historical issue; with a specifically Māori or generally New Zealand topic; whether Férey mentions it once or several times; as well as whether it is voiced by the narrator, by a protagonist or by an antagonist. However, none of these groupings fully and completely accounts for the changes in French responses. I found only one feature that partially correlates with French responses: for all seven of the statements for which their responses showed no statistically significant difference before and after reading, New Zealand respondents also showed no statistically significant difference in their opinions, suggesting an absence, rather than source, of influence. Therefore, although I accept H2, I am unable to extrapolate from my results to predict the type of cultural information that will or will not influence cultural outsider readers' opinions.

Although I cannot claim an overall schema for what type of information is culturally persuasive, it is informative to look at the seven statements that swayed French readers. While for three of them - S4, S15, and S17 - it was unlikely that French participants would possess relevant prior knowledge before reading $U t u$, for the remaining four - S3, S7, S23, and S26 - they could have 'guessed' that they should agree by either drawing analogies with France or from general knowledge. First, S3, in which Férey depicts South Auckland as the banlieue, a concept familiar to French people, meaning the low socio-economic, high crime area on a city's outskirts, but one French participants rejected before reading $U t u$, perhaps believing New Zealand too quiet a country or Auckland too small a city to have such areas. The second, S7, treats nineteenthcentury Māori cannibalism, depicted by Jules Verne in Les Enfants du Capitaine Grant (1868), which Férey claims as a formative childhood text (Angelier). The third, S23, is about Māori in prison. Given that indigenous peoples are overrepresented in many countries' prison populations, French participants could have guessed the answer by association. That they did not may signal a French exception due to republican ideals of equality, which forbid the collecting and/ or reporting of statistics based on racial or ethnic origin (Schnapper 133). Finally, S26, shrunken heads. The New Zealand Government is making a concerted effort to have all kōiwi tangata (ancestral remains) held by museums outside New Zealand returned to Māori care (Hole 5). In January 2012, the French government held a ceremony at Quai Branly, the ethnographic museum in Paris, to return twenty such heads (Mortaigne), which was reported in French newspapers and on television.

\section{Hypothesis Three: That the perceived source of the geographically- and cul- turally-situated information influences reception}

Despite the mixed outcome of $\mathrm{H} 2$, I wanted to further explore one factor by testing a third null hypothesis: $\mathrm{H}_{0} 3-$ that readers are equally influenced by geographically- and culturally-situated information regardless of perceived source. In this I was aided by Férey's 
creation of an antagonist called Melrose, whom Férey intends the reader to detest. Even before we meet Melrose, he is described as an extremely right-wing, racist, multi-millionaire businessman who writes self-published history books about New Zealand that have become bestsellers (French 59-60; English 51-52). A lengthy anti-Māori, neoliberal diatribe by Melrose $(159-60 ; 133-34)$ is the source of seven of my twenty-seven statements. Looking at pre- and post-reading responses to these seven 'Melrose' statements shows that French participants changed their opinion from disagree (pre-reading) to agree (post-reading) for three of them (S7, S15, S17), disagreed less strongly with one of them (S16), and did not change their opinion for another three (S14, S18, S19). Therefore, I could not reject $\mathrm{H}_{0} 3$ but instead looked within these seven statements to develop two null subhypotheses $\left(\mathrm{H}_{0} 3 \mathrm{a}-\mathrm{b}\right)$ for two subgroups of information:

$\mathrm{H}_{0} 3 \mathrm{a}$ Readers are equally influenced by historical or contemporary information conveyed via Melrose.

Looking at data for the first null hypothesis-- $\mathrm{H}_{0} 3 \mathrm{a}--$ shows that French readers were less willing to change their opinions about contemporary society-about whether Māori today are drunkards (S18), warriors (S16) or poor parents (S19)--than about historical issues such as nineteenth century cannibalism (S7) or exterminating nineteenthcentury enemies (S15, S17). Therefore I rejected the null hypothesis $\mathrm{H}_{0} 3 \mathrm{a}$ and accepted hypothesis $\mathrm{H} 3 \mathrm{a}$ "that readers are more influenced by historical than contemporary information conveyed via Melrose." Turning to the second null hypothesis $-\mathrm{H}_{0} 3 \mathrm{~b}$ - shows that French participants were more willing to change their opinion about statements treating 'facts' (S7, S15, S17) rather than 'attitudes' (S14, S16, S18, S19), thus I rejected the null hypothesis for $\mathrm{H}_{0} 3 \mathrm{~b}$ and accepted hypothesis $\mathrm{H} 3 \mathrm{~b}$ "that readers are more influenced by facts than attitudes conveyed via Melrose."

Given Férey's left-wing politics, he might be dismayed that his readers accepted anything from Melrose. However, I have three possible explanations for why French readers are susceptible to factual and historical information despite the perceived source. Firstly, by the time readers came across these statements Férey seems to have convinced them of his expertise in all matters Māori and New Zealand, meaning that information presented as 'facts'--even from Melrose-seemed credible. Secondly, it may be due to increasing memory externalisation. Search engines provide access to a universal archive so why should these student participants memorise dates of the Kings and Queens of France, or details of the Land Wars, when the answer is only a search away and mental effort can instead be directed towards following the latest celebrity gossip? This is perhaps especially true for 'facts' that readers feel they will never be required to regurgitate, such as those offered during leisure reading of crime fiction. Finally, in establishing Melrose, Férey may have done himself a disservice by labouring the point that Melrose self-published his bestselling history books, since the world has moved on to publishing phenomena such as Fifty 
Shades of Grey (James), which began as a self-published e-book before being picked up by Random House (Knox 54). While this might be anathema for established authors, popular fiction readers now seem not to regard 'self-publishing' as automatically equating to 'lower quality' (Fay). Thus (student) readers today may equate '(fictional) author of history books' with 'credible source of historical facts.'

\section{Hypothesis Four: That French readers} change their attitudes to New Zealand and New Zealanders based on their reading of a novel set in that country

Having looked at the micro-effects--how readers reacted to the world portrayed within Férey's novel--I turn now to the macro-picture: did Utu influence French readers' attitudes towards New Zealand and New Zealanders in general? Both before and after reading Utu I asked French participants to respond to eight attitudinal statements (see Table 2) that explore their general attitudes to the country and its citizens rather than about the specific issues raised in Utu about geography, politics, anthropology, history or society. My null hypothesis $-\mathrm{H}_{0} 4$ - is "that French readers' attitudes to New Zealand and New Zealanders are unaffected by reading Utu." I found a statistically significant change in mean response to $\mathrm{A} 2, \mathrm{~A} 4$ and $\mathrm{A} 7$ (at the 0.05 level) as well as A3 and A8 (0.1 level) so I rejected $\mathrm{H}_{0} 4$ and accepted $\mathrm{H} 4$ : "that French readers change their attitudes to New Zealand and New Zealanders based on their reading of a novel set in that country." However, in all five cases the mean responses moved in the opposite direction to that which might be desired by Tourism New Zealand: after reading Utu, French participants thought New Zealand less safe to visit (A2), that visitors would be more likely to be victims of crime (A4, A7), and that New Zealanders are less friendly and likeable (A3, A8).[3]

I did not find a statistically significant change for A1: "I will visit New Zealand within the next three years," with participants disagreeing slightly both before and after reading. Just as Bayard argues that it is unnecessary to experience places first-hand in order to write about them, readers can also be content with literary, rather than physical, voyaging. To Bayard's physical and psychological inconveniences of travel (13), one can add the high cost in time and money a trip to New Zealand involves, making it unimaginable for most university students.

\section{Conclusion}

I have provided empirical evidence that a novel's geographically and culturallysituated elements differently influence cultural insider and outsider readers, with the latter more likely to change their opinions than the former. Moreover, for every statement that showed a statistically significant difference between pre- and post-reading means, readers' opinions moved towards the image portrayed by Férey in Utu, not only for outsider French readers but also for New Zealanders, even when Férey's cultural claim was incorrect.

Furthermore, for cultural outsiders this influence extends beyond Utu's final page to opinions about the country depicted. At first sight, readers' negative attitudes 
to Férey's dark depictions might seem bad news for New Zealand given that tourism represents $8.5 \%$ of its GDP (Statistics New Zealand 9). However, there are two reasons why Utu may in fact be beneficial. First, New Zealand markets itself to thrill seekers through international advertising campaigns with images of adventurous activities such as bungy-jumping and white-water rafting set amid its rugged landscape; such potential tourists are unlikely to be deterred by (fictional) cannibalism. Second, most of Férey's French readers never intended travelling beyond the novel's covers but nonetheless closed it with a new perspective on the country and its people. Perversely, it matters not that this perspective is negative; the simple fact of having read a novel about little-known New Zealand boosts the country's intangible reputation within the French imaginary. To support this claim, I turn to Berger, Sorensen and Rasmussen, who show that "Whereas a negative review [in the New York Times] decreased purchase likelihood of a book that was already well known, it increased purchase likelihood for a previously unknown book" (824). By analogy, Utu's negative 'review' of previously unknown New Zealand helps the country's name recognition; any publicity is good publicity.

\section{Acknowledgements}

I would like to thank Emeritus Professor Ian Carter for enrolling study participants at the University of Auckland as well as two anonymous reviewers for their insightful comments. This research was supported financially by the University of Auckland Faculty of Arts Doctoral Research Fund. Approval for this study was given by the University of Auckland Human Participants Ethics Committee (2011/417).

\section{Endnotes}

[1] I refer to the 'French' and 'New Zealand' cohorts in this article although both contain members who were neither born in nor citizens of those countries. I received too few postreading questionnaires to find statistically significant differences between subgroups within each cohort, for example between the nineteen New Zealand-born versus five non-New Zealand born postreading respondents comprising the $\mathrm{New}$ Zealand' cohort.

I aimed to enrol 120 in each group, a number arrived at from a priori sample sizes ( $\mathrm{G}^{\star}$ Power v.3.1.3, Faul et al.) calculated from the results of a pilot study and allowing for predicted response rates, (Scott et al. 6; Kaplowitz, Hadlock and Levine; Baruch and Holtom; Nair and Adams 295; Sax, Gilmartin and Bryant 417; Deutskens et al. 29), the establishment of a gift/obligation relationship (Smart 389), the requirement to read a long, violent noir novel and my repeated measures design (Gardner 10709 ) as well as two logistical issues: funding and the number of enrolled students.

[2] Kolmogorov-Smirnov test results showed that pre- and post-reading responses to the twenty-seven statements for both French and New Zealand participants and to the eight attitudinal statements for the French participants were not normally distributed. Therefore 
I used non-parametric statistical tests throughout this analysis (Black 550-551). Unless otherwise stated, statistically significant difference is at the 0.05 level.

[3] A3 and A8, as well as having a lower statistical significance, are problematic because the results may have been influenced by my actions as a researcher. Participants completed the pre-reading survey immediately after I had spoken to them and had given them a free copy of the novel, perhaps leading them to believe that I, and by extension, other New Zealanders are friendly and likeable, and moving the pre-reading mean to a more positive value. However, after having read a violent novel--and the effect of meeting me having worn off-participants reported lower scores, perhaps representing a truer opinion.

\section{Works Cited}

"American Requiem [Interview with Caryl Férey]." Mauvais genres. France Culture. 28 Apr 2012. Radio.

Auruskeviciene, Vilte, et al. "Change of Attitudes and Country Image after Hosting Major Sport Events." Inzinerine Ekonomika - Engineering Economics 21.1 (2010): 53-59. Print.

Barber, Ian. "Archaeology, Ethnography, and the Record of Maori Cannibalism before 1815: A Critical Review." Journal of the Polynesian Society 101.3 (1992): 241 92. Print.

Barker, Martin, and Ernest Mathijs. "Researching World Audiences: The Experience of a Complex Methodology." Participations 9.2 (2012): 664-89. Print.
Baruch, Yehuda, and Brooks C. Holtom. "Survey Response Rate Levels and Trends in Organizational Research." Human Relations 61.8 (2008): 1139-60. Print.

Bayard, Pierre. Comment Parler Des Lieux Où L’on N’a Pas Été? Paris: Les Éditions de Minuit, 2012. Print.

Berger, Jonah, Alan T. Sorensen, and Scott J. Rasmussen. "Positive Effects of Negative Publicity: When Negative Reviews Increase Sales." Marketing Science 29.5 (2010): 815-27. Print.

Black, Thomas R. Doing Quantitative Research in the Social Sciences: An Integrated Approach to Research Design, Measurement and Statistics. London: Sage, 1999. Print.

Carroll, Joseph, et al. "Graphing Jane Austen: Agonistic Structure in British Novels of the Nineteenth Century." Scientific Study of Literature 2.1 (2012): 1-24. Print.

Carter, Ellen, and Deborah WalkerMorrison. "Cannibalistic Māori Behead Rupert Murdoch: (Mis)Representations of Antipodean Otherness in Caryl Férey's 'Māori Thrillers"' The Foreign in International Crime Writing: Transcultural Representations. Eds. Anderson, Jean, Carolina Miranda and Barbara Pezzotti. London: Continuum, 2012. 9-21. Print.

Childress, C. Clayton, and Noah E. Friedkin. "Cultural Reception and Production: The Social Construction of Meaning in Book Clubs." American Sociological Review 77.1 (2012): 45-68. Print. 
Crofts, Stephen. "Cross-Cultural

Reception Studies: Culturally

Variant Readings of Crocodile

Dundee." Continuum 6.1 (1992): 213-27.

Print.

Deutskens, Elisabeth, et al. "Response

Rate and Response Quality of Internet-

Based Surveys: An Experimental

Study." Marketing Letters 15.1 (2004): 21 -

36. Print.

Faul, Franz, et al. "Statistical Power

Analyses Using $G^{\star}$ Power 3.1: Tests

for Correlation and Regression

Analyses." Behavior Research Methods 41.4

(2009): 1149-60. Print.

Fay, Sarah. "After 'Fifty Shades of Grey',

What's Next for Self-Publishing?". The

Atlantic. 2 Apr. 2012. 4 July 2012.

$<$ http://www.theatlantic.com/

entertainment/archive/2012/04/after-

fifty-shades-of-grey-whats-next-for-self-

publishing/255338/.>.

Férey, Caryl. Utu. Paris: Gallimard, 2004.

Print.

Férey, Caryl. Utu. Paris: Gallimard, 2008.

Print.

Férey, Caryl. Utu. Trans. Curtis, Howard.

New York, NY: Europa, 2011. Print.

Férey, Caryl. Zulu. Paris: Gallimard, 2008.

Print.

Gardner, Robert C. Psychological Statistics Using SPSS for Windows. Upper Saddle

River, NJ: Prentice Hall, 2001. Print.
George, Richard. "Visitor Perceptions of Crime-Safety and Attitudes Towards Risk: The Case of Table Mountain National Park, Cape Town." Tourism Management 31.6 (2010): 806-15. Print.

Halász, László, Mick Short, and Ágnes

Varga. "A Cross-Cultural Study of

Fictional and Non-Fictional Text

Understanding." Poetics 30.3 (2002): 195 219. Print.

Hole, Brian. "Playthings for the Foe: The Repatriation of Human Remains in New Zealand." Public Archaeology 6.1 (2007): 5-27. Print.

James, E.L. Fifty Shades of Grey. London: Arrow, 2012. Print.

Kaplowitz, Michael D., Timothy

D. Hadlock, and Ralph Levine. "A Comparison of Web and Mail Survey Response Rates." Public Opinion Quarterly 68.1 (2004): 94-101. Print.

Knox, Malcolm. "Randy House." The Monthly Apr. 2012: 54-55. Print.

"Making a Claim." Waitangi

Tribunal. Wellington, n.d. 14 Nov 2012. $<$ http://www.waitangi-tribunal.govt.nz/ claims/making_claim.asp $>$.

Mortaigne, Véronique. "La Force Vitale Des Maori Submerge Le Quai Branly." Le Monde 11 Oct 2011. Print.

Nair, Chenicheri Sid, and Phillip Adams. "Survey Platform: A Factor Influencing Online Survey Delivery and Response Rate." Quality in Higher Education 15.3 (2009): 291-96. Print. 
Richardson, Alan. "Studies in Literature and Cognition: A Field Map." The Work of Fiction: Cognition, Culture, and Complexity. Eds. Richardson, Alan and Ellen Spolsky. Aldershot: Ashgate, 2004. 1-30. Print.

Salmond, Anne. Trial of the Cannibal Dog: The Remarkable Story of Captain Cook's Encounters in the South Seas. New Haven, CT: Yale University Press, 2003. Print.

Sax, Linda J., Shannon K. Gilmartin, and Alyssa N. Bryant. "Assessing Response Rates and Nonresponse Bias in Web and Paper Surveys." Research in Higher Education 44.4 (2003): 409-32. Print.

Schnapper, Dominique. "Les Enjeux Démocratiques De La Statistique Ethnique." Revue Française de Sociologie 49.1 (2008): 133-39. Print.

Scott, Anthony, et al. "A Randomised Trial and Economic Evaluation of the Effect of Response Mode on a Response Rate, Response Bias, and Item Non-Response in a Survey of Doctors." BMC Medical Research Methodology 11 (2011): 126 pp. $<$ http://www.biomedcentral.com.ezproxy. auckland.ac.nz/1471-2288/11/126>.

Smart, Alan. «Gifts, Bribes, and Guanxi: A Reconsideration of Bourdieu>s Social Capital.» Cultural Anthropology 8.3 (1993): 388-408. Print.

Statistics New Zealand. Tourism Satellite Account: 2012. Wellington: Statistics New Zealand, 2012. Print.

Verne, Jules. Les Enfants Du Capitaine Grant. Paris: Éditions Hetzel, 1868. Print.
Ellen Carter is a PhD student jointly enrolled at the University of Auckland, New Zealand, and the École des Hautes Études en Sciences Sociales, Paris, France. Her research centres on how cultural outsiders write, translate and read crosscultural crime fiction.

Ellen Carter est étudiante au doctorat en co-tutelle avec l'université d'Auckland en Nouvelle-Zélande et l'École Des HautesÉtudes en Sciences Sociales à Paris. Ses recherches portent sur les lectures, les écritures, et les traductions excentrées du récit policier.

This article is licensed under a Creative Commons 3.0 License although certain works referenced herein may be separately licensed, or the author has exercised their right to fair dealing under the Canadian Copyright Act.

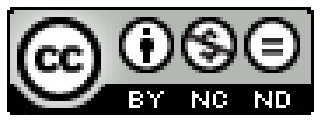

